NBER WORKING PAPER SERIES

\title{
THE CORRELATION OF WEALTH ACROSS GENERATIONS
}

\author{
Kerwin Kofi Charles \\ Erik Hurst \\ Working Paper 9314 \\ http://www.nber.org/papers/w9314
NATIONAL BUREAU OF ECONOMIC RESEARCH 1050 Massachusetts Avenue
Cambridge, MA 02138
October 2002

\begin{abstract}
We thank Heidi Shierholz for excellent research assistance and participants at the NBER 2000 summer consumption workshop, the University of Chicago's Graduate School of Business macro lunch, the University of Michigan's labor seminar, Dartmouth's economic workshop, Wisconsin's public finance workshop, University of Maryland's macro seminar, University of Florida's applied economics workshop and Purdue University's macro/international workshop for helpful comments. Additionally, we would like to thank Mark Aguiar, Orazio Attanasio, Rebecca Blank, John Bound, Sam Bowles, Charlie Brown, John Cochrane, Steve Davis, Anil Kayshap, Kevin Lang, Glen Loury, Anna Lusardi, Casey Mulligan, Karl Sholz, Jonathan Skinner, Gary Solon, and Nick Souleles. Hurst would also like to thank the financial support given by the William Ladany Research Fund at the Graduate School of Business, University of Chicago for work on this project. The views expressed herein are those of the authors and not necessarily those of the National Bureau of Economic Research.
\end{abstract}

(C) 2002 by Kerwin Kofi Charles and Erik Hurst. All rights reserved. Short sections of text, not to exceed two paragraphs, may be quoted without explicit permission provided that full credit, including (C) notice, is given to the source. 
The Correlation of Wealth Across Generations

NBER Working Paper No. 9314

October 2002

JEL No. J62, J12, G12, E21

\section{ABSTRACT}

This paper examines the similarity in wealth between parents and their children, and explores alternative explanations for this relationship. We find that the age-adjusted elasticity of child wealth with respect to parental wealth is 0.37 , before the transfer of bequests. Lifetime income and ownership of particular assets, both of which exhibit strong intergeneration similarity, jointly explain nearly two-thirds of the wealth elasticity. Education, past parental transfers, and expected future bequests account for little of the remaining elasticity. Using new experimental evidence, we assess the importance of risk tolerance. The risk tolerance measures vary as theory would predict with the ownership of risky assets, and are highly correlated between parents and children. However, they explain little of the intergenerational correlation in the propensity to own different assets, suggesting that children's savings propensities are determined by mimicking their parents' behavior, or the inheritance of preferences not related to risk tolerance. Additionally, these risk tolerance measures explain only a small part of the remaining intergenerational wealth elasticity.

Kerwin Kofi Charles

Department of Economics

University of Michigan

Ann Arbor, MI 48109-1220

and NBER

kcharles@umich.edu
Erik Hurst

Graduate School of Business

University of Chicago

1101 East 58th Street

Chicago, IL 60637

erik.hurst@gsb.uchicago.edu 


\section{Introduction}

How likely are the children of wealthy parents to be wealthy as well? What accounts for this association? Do wealthy parents have wealthy children because they: (a) invest in their children's education, raising their income and wealth? (b) give their children financial gifts, which raises their wealth directly, and provide them credit and insurance so that they are more likely to undertake potentially risky investments? or (c) pass on similar savings propensities? Despite their implications for understanding the persistence of economic inequality, there is little empirical evidence on these questions. This paper examines the extent of the intergenerational relationship in wealth for a nationally representative sample of parent-child pairs. In addition, it separates among possible explanations for this relationship.

We estimate a simple regression of the log of child's wealth on the log of parents' wealth. When the only other controls in this regression are child and parental age, the coefficient on parental wealth measures the age-adjusted elasticity of child wealth with respect to parental wealth. Adding parent and child controls that determine household wealth to the regression establishes how much of the intergenerational wealth elasticity is attributable to parent-child similarity in these controls. We find an age-adjusted intergenerational wealth elasticity of 0.37 , implying that parents whose wealth is fifty percent above the mean in the parents' generation have children whose wealth is eighteen percent above the mean in the children's generation.

We estimate the intergenerational wealth elasticity from a sample where both parents and children are still alive, so ours is an estimate of the parent-child wealth relationship before the transfer of bequests. As we explain below, data limitations prevent us from studying how the wealth of parents and children is related after the transfer of bequests, though we are able to study the effect of previous gifts and expected future bequests. Given the obvious importance of bequests, what is the gain from studying the pre-bequest relationship? Because a child who receives bequests from 
his parents will do so only upon their deaths, someone born to parents in their mid-twenties may be well into his fifties before he receives a bequest from them. The pre-bequest wealth relationship we study in this paper therefore explores why parents and children have similar wealth for the majority of their lives. This analysis will allow us to assess intergenerational similarities in saving propensities, conditional on lifetime resources.

We find that standard inputs to household wealth accumulation - income, human capital, and the ownership of particular assets - are highly correlated between parents and their children. Similarities in the level, growth and variance of lifetime income, the dimensions of income emphasized in the theoretical wealth literature, alone account for one half of the parent-child wealth relationship. The tendency for parents and children to own the same assets is the next most important factor, accounting by itself for thirty-six percent of the wealth elasticity, and for an additional twelve percent after accounting for income. By contrast, education, previous large financial gifts and expected future bequests explain virtually none of the intergenerational wealth elasticity, after controlling for income.

Almost thirty-five percent of the intergenerational wealth elasticity remains unexplained after controlling for income, asset ownership propensity, education, gifts and expected bequests. What are the other mechanisms for wealth transmission? Preferences are a possible candidate. In the final portion of the paper, we study new, experimental survey data on risk tolerance. We find that parents and children have similar preferences for risk, especially at the tails of the risk tolerance distribution. Also, persons with higher risk tolerance hold riskier assets, as theory would suggest. However, risk tolerance explains only a small amount of the propensity for parents and children to own the same asset, suggesting that this association derives either from the tendency of children to mimic their parents' investment behavior or from intergenerational similarity in some aspect of preferences not related to risk. Finally, we find that the risk tolerance measures explain little of the 
remaining intergenerational wealth elasticity after controlling for income and asset ownership. There is thus a residual portion of the parent-child wealth relationship which we cannot explain.

Aside from Mulligan (1997), the few previous authors who have studied the intergenerational wealth association have used samples from very specialized sub-populations drawn from late $19^{\text {th }}$ and early $20^{\text {th }}$ century 1 Although wealth was not the primary focus of his analysis, Mulligan reports estimates of the elasticity in log wealth between parents and their children of between 0.32 and 0.43 . Mulligan, however, does not attempt to separate between different explanations for the parent-child wealth relationship.

Of the intergenerational relationships which can affect the similarity in parent-child wealth, the one which has received the most independent attention is the intergenerational relationship in income. The consensus is that the elasticity of log child earnings with respect to their log parents' earnings is between 0.4 and 0.6, after accounting for measurement error (Mulligan (1997) and Solon (1999)). Few papers have looked at how the growth rate and variances of parents' and child's incomes are related, and no one has studied how much of the intergenerational wealth relationship is attributable to the aspects of lifetime income emphasized in the theoretical literature.

Venti and Wise (2000) show that at all levels of lifetime earnings there is great dispersion in the amount of accumulated assets. Only a handful of papers have looked at direct evidence on the extent of heterogeneity in household savings preference parameters, although none examines whether these preferences are related between parents and children (Lawrence (1991), Barksy, Juster, Kimball and Shapiro (1996), Samwick (1998) and Warner and Pleeter (2001)). Work on

\footnotetext{
1 Menchik (1979), Kearl and Pope (1986) and Wahl (1995) relate child and parent wealth for historical samples.

2 See Mulligan (1997) and Solon (1999) for recent surveys on the income correlations literature. See also Altonji and Dunn (1991, 2000), Solon (1992, 1999), Zimmerman (1992), Mulligan (1996, 1997), Ham and Mulligan (2000) and Shea (2000). Cox, $\mathrm{Ng}$, and Waldkirch (2001) document intergenerational consumption linkages. Altonji, Hayashi and Kotlikoff (1992) test for whether parents are altruistic towards their children.

${ }^{3}$ Standard life-cycle models of wealth accumulation suggest that wealth depends on 1) the level of lifetime income, 2) the trajectory of lifetime income and 3) the propensity to save out of given lifetime income levels and trajectories. See Modigliani and Brumberg (1954) and Friedman (1957). Extensions to the basic model argue that the expected future variance of income matters as well (Deaton (1991), Carroll (1994)).
} 
intergenerational correlations in portfolio composition is equally sparse (for exceptions, see Chiteji and Stafford (2000) and Hurst and Lusardi (2002)).

\section{DATA}

We use data from the Panel Study of Income Dynamics (PSID). The PSID is a large nationally representative survey started in 1968 which tracks the socio and economic variables of a given family over time. In each year of the survey, demographic questions such as age, race, family composition, and education levels are asked of all members of the households. Among other information, the survey asks each household detailed questions about labor market participation and earned labor income.

Occasionally, the PSID supplements the main data set with special modules. In 1984, 1989, 1994 and 1999, the PSID asked households extensive questions about their wealth. For the measure of wealth, we sum the household's holding of real estate - own or main home, second home, rental real estate, land contract holdings - cars, trucks, motor homes, boats, farm or business, stocks, bonds, mutual funds, saving and checking accounts, money market funds, certificate of deposit, government savings bonds, Treasury bills, Individual Retirement Accounts, bond funds, cash value of life insurance policies, valuable collections for investment purposes, and rights in a trust or estate, less mortgage, credit card, and other debt on such assets. Aside from pensions (both private and public), the PSID data provides a relatively complete picture of household financial wealth.

The PSID was designed, in part, to study economic mobility across generations. As such, the data set takes uncommon care to track and survey children of core sample respondents. The children of core sample members become part of the PSID core sample as they leave their parents' household and form their own households. All new households that have become part of the PSID

\footnotetext{
${ }^{4}$ See Hurst, Luoh and Stafford (1998) and Juster, Smith and Stafford (1999) for a complete description of the PSID wealth data and discussion of how the data compares to wealth information from other sources.
} 
after the original sample was formed are the children or grandchildren of that original sample. This intergenerational feature of the sample design makes the PSID a good data set to analyze the similarity of wealth position between parents and children.

We study families with children between 25 and 65 in the 1999 survey, and with parents who were part of the survey in 1984, 1989 and 1999, and who were not retired in 1984 and 1989 when parental wealth is measured. We emphasize non-retirement status in order to capture households during the time in their life cycles when they are accumulating wealth. Parental wealth is measured as the average of their reported wealth in both 1984 and 1989, and child wealth is measured in 1999 .

This paper does not address the effect of bequests to children after parental death on the intergenerational wealth relationship. The sample includes only families in which the child in 1999 has at least one core sample parent known to be alive in 1999. In fact, the vast majority of available parent-child pairs in the data are of this type. As late as the 1999 PSIID survey, there were only 70 parent-child pairs in which both non-retired parents in 1984 were known to have died. Studying the effect of bequests on the intergenerational wealth relationship in datasets like the PSID, in which panel information is available about different generations of families, will not be possible for many years yet. The empirical work does assess the impact of expected future bequests on the parentchild wealth relationship.

We limit the sample to families in which both the parents and children have positive wealth in the years measured. Doing so allows us to measure the association in log-wealth between parents and their children, which is more directly comparable to the measures of the intergenerational income elasticities reported in the literature. Imposing this restriction causes us to drop only a handful of observations from the sample. About $8 \%$ of the children and less than $1 \%$ of the parents

\footnotetext{
${ }^{5}$ Ideally, we would like to measure parents' and children's wealth at the same age, but we are prevented from doing so by the fact that the wealth measures in the PSID are currently at most fifteen years apart.
} 
had negative or zero reported net worth. The basic facts about the elasticities that we present, particularly in the transition matrix results, are not at all sensitive to this restriction.

The analysis sample consists of 1,491 parent-child pairs. ${ }^{6}$ Table 1 presents the means and standard deviation of key variables for both parents and children. In this table, and throughout the paper, all dollar values are reported in 1996 dollars. The first row of the table shows that children in the sample were about 15 years younger in 1999, on average, than their parents were in 1984. Because both wealth and income have a strong age component, we focus on age-adjusted wealth measures in the work which follows. The age differences between parents and children may also account for the fact that parents had more income, more wealth, and larger asset ownership rates.

The last four rows in the table reveal the extreme skewness of the wealth distribution. For example, among children, the difference between the $20^{\text {th }}$ and $40^{\text {th }}$ percentile is about $\$ 50,000$, whereas the difference between the $60^{\text {th }}$ and $80^{\text {th }}$ percentile is almost double that. Comparable numbers are evident among parents. We use the natural $\log$ of wealth in the regressions presented later to account for this skewness.

\section{Elasticity of Child Wealth with Respect to Parental Wealth}

To estimate the age-adjusted elasticity of child's wealth with respect to parent's wealth, we estimate the regression:

$$
W_{k}=\alpha+\delta_{1} W_{p}+\beta_{1 k} A g e_{k}+\beta_{2 k} A g e_{k}^{2}+\beta_{1 p} A g e_{p}+\beta_{2 p} A g e_{p}^{2}+\varepsilon_{k}
$$

where $W_{k}$ and $W_{P}$ measure the natural log wealth of the child, $k$, and parent, $p$, respectively; $A g e_{k}$, $A g e_{k}^{2}, A g e_{p}$ and $A g e_{p}^{2}$ measure their ages and the square of their ages at the time they are observed;

\footnotetext{
6 There were about 250 parents who were in the sample in 1984 but dropped out of the sample prior to 1999 . We also removed these parent-child pairs from the sample because we were could not determine whether the parents had died during the intervening years. We estimated all of the regressions with and without these households included and the results were essentially unchanged.
} 
and $\varepsilon_{k}$ is an error term. The regression coefficient $\delta_{1}$ in 11 measures the age-adjusted intergenerational wealth elasticity.

The fact that available wealth data is likely fraught with measurement error complicates this straightforward estimate of the wealth correlation. Given that it would be absorbed into $\varepsilon_{\mathrm{k}}$, classical measurement error is irrelevant for the child wealth variable in a regression such as (1). However, classically mis-measured parental wealth would produce an attenuated estimate of the intergenerational wealth correlation. To deal with this problem, we follow the lead of previous work in the income correlations literature, and exploit the panel structure of the available data, by measuring parental wealth as the average of reported wealth over multiple time periods. 7 Henceforth, the parental wealth measure is the average of parental wealth over the 1984 and 1989 survey years.

Estimating (1) by OLS, we find an age-adjusted elasticity of child wealth with respect to parental wealth of 0.37 , with a $t$-statistic of more than 10 . This implies that parents whose wealth is 10 percent above the mean in their generation, have children who, before any parent-child bequests are transferred, have wealth which is 3.7 percent above the mean in the children's generation. ${ }^{8}$

We also examine parents' and children's relative positions in the age-adjusted wealth distributions. We first regress child and parent log wealth on age and age squared. We then split the residuals from these two regressions into five equal segments, and create a parent-child wealth transition matrix. Each element $\pi_{a b}$ of the matrix indicates the probability that a child belongs to the $a^{\text {th }}$ quintile of the distribution for children, given that her parents belong to the $b^{\text {th }}$ quintile of the parental distribution. The more independent children's and parents' wealth, the greater the

\footnotetext{
7 See Solon (1992) for a similar approach with respect to income, and see Zimmerman (1992) for a useful discussion of potential biases in income correlations.

8 Even though we average parental wealth over 1984 and 1989, our estimate of $\delta_{l}$ may still be biased downward. Following the intergenerational income literature, we instrumented for parental wealth using parental education. The instrumented estimate of $\delta_{l}$ was 0.590 . We do not highlight this estimate because it is likely biased upwards. Parental education can have a direct effect on child's wealth, even when controlling for both child's education and income.
} 
likelihood that the elements of this transition matrix should be close to one-fifth. The greater the departure of the elements of the transition matrix from 0.2 , the greater the intergenerational similarity in relative age-adjusted wealth position. The transition matrix method shows the intergenerational persistence of wealth at different points in the wealth distribution, accounting for the fact that the linear functional form assumed in (1) may be incorrect.

Table 2 presents the intergenerational transition matrix of age-adjusted log wealth. The evidence about persistence in this table is consistent with the estimated wealth elasticity from the regression. Reading down the first column, for example, the matrix indicates that $36.1 \%$ of parents in the lowest age-adjusted wealth quintile have children whose wealth places them in that same quintile in the children's adjusted wealth distribution. Indeed, only $30 \%$ of parents in the lowest quintile have children whose wealth places them in any of the three highest wealth quintiles in the child distribution, and only $7 \%$ of children whose parents were in the lowest wealth quintile make it to the highest quintile. Thus, despite modest mobility within the wealth distribution, the numbers indicate that the overwhelming majority of children are unable to break free from the low wealth status of their parents.

Similar persistence is evident at the other tail of the parental wealth distribution. Thirty-six percent of high wealth parents have children who end up in the top quintile of the child's age adjusted wealth distribution, and almost seventy-percent have children whose wealth places them in the top two wealth quintiles. Only $11 \%$ of the children of high wealth parents fall to the lowest quintile.

Overall, the table depicts substantial persistence in wealth position from parents to children. Throughout the matrix, the probability that a child ends up in a wealth quintile different from the one occupied by his parent tends to be monotonically decreasing the further away that quintile is from the parents'. Children are most likely to fall into a wealth quintile exactly like that of their 
parents, and are very unlikely to end up in a dramatically different one. A likelihood ratio chisquared test confirms the persistence evident in the table: we can strongly reject the hypothesis that the entries in the adjusted wealth position transition matrix are equal to each other at any standard statistical level ( $p$-value $<0.001)$.

\section{Decomposing the Intergenerational Wealth Elasticity}

There are several reasons why parent and child wealth would be similar. First, wealth, unlike income, is directly transferred between generations. Second, income is correlated between parents and their children. The theoretical literature that sets out to explain the documented intergenerational earnings correlation often does so by invoking the existence of capital market imperfections (Becker and Tomes (1979, 1986), Loury (1981)). If children find it difficult to borrow against their future income to accumulate human capital, high-income parents will be more able to relax the liquidity constraints faced by their children. Consequently, the children of highincome parents will have both higher levels of education and income. Controlling for income will partially capture the extent to which capital market imperfections cause the intergenerational correlation in wealth. In our decompositions below, we also examine the effect of human capital accumulation directly.

Additionally, even if capital markets are perfect, controlling for parent and child income captures any intergenerational correlation in innate ability or preferences that affect earnings directly, such as work ethic. Finally, parents and children could have similar wealth because they have similar propensities to save out of any given income stream. In many standard models, the preference parameters that determine how much a household will save out of income also determine in which assets the household will save (see Browning and Lusardi (1996) and the cites within). As a result, controlling for household asset composition, in part, proxies for household savings propensities. 
In this section we assess how much of the parent-child wealth relationship documented above derives from parent-child similarities in income, education, and the propensity to own specific assets. Additionally, we consider how much of the intergenerational wealth elasticity is due to the direct transfer of wealth in the form of expected future bequests and past parental gifts.

Table 3 shows that parents and their children do, in fact, have correlated levels of family income, education and portfolio composition. The table presents results from a series of simple regressions in which the child's value of a given variable is regressed on the same variable for the parent, and age controls for both the parents and children. If the variable is a binary variable, the corresponding regression is estimated as a linear probability model.

The first entry shows that the elasticity of the level of child family income with respect to the parent's is 0.3 . We measure the child's family income as the average of husband and wife's labor income between 1992 and 1996 and the parent's family income as the average of the husband and wife's income between 1983 and 1987. Our estimated income correlation is lower than that reported by Solon (1992) and Mulligan (1997), but this is not surprising given that their results refer to the elasticity between individual fathers and sons, and ours is the elasticity between fathers' and sons' families. The latter correlation will be lower so long as mating is not perfectly assortative with respect to income.

Table 3 also shows that education is also very similar between parents and their children. For example, the results indicate that having a parent who has some college education makes a child thirty-two percentage points more likely to be a have college training - a very large marginal effect given the mean college training rate among children is fifty-six percent.

The next set of entries in the table show the intergenerational similarity in asset ownership. The results indicate that having a parent who owns either stocks, a businesses or a home makes a child much more likely to own the same asset as well. The estimated effect is strongly statistically 
significant in each case, and for all of the assets, represents a large increase over the mean rate of asset ownership.

The association in asset ownership propensity may be simply due to fact that parental and child lifetime incomes are similar. The final entries in the table show the similarity in asset ownership between children and parents, after controlling for income and income squared. For each asset category, controlling for income reduces the estimated parent-child relationship. However, for both business ownership and home ownership, the effect of parental portfolio ownership remains strong even after controlling for income. ${ }^{9}$ On the other hand, it appears that the intergenerational correlation in stock ownership is exclusively a result of the intergenerational correlation in income. Though we do not present the results, controlling for parental wealth in addition to income yields basically the same results as the last set of numbers. These results suggest that asset ownership is not similar between parents and children because wealthy parents relax liquidity constraints or otherwise provide downside risk insurance to their children.

To determine how much of the intergenerational wealth elasticity derives from the similarity between parents and children in income, education and asset choice and how much derives from direct transfers such as gifts and expected bequests, we estimate a series of regressions of the form:

$$
W_{k}=\alpha+\delta_{2} W_{p}+\beta_{1 k} A g e_{k}+\beta_{2 k} A g e_{k}^{2}+\beta_{1 p} A g e_{p}+\beta_{2 p} A g e_{p}^{2}+\alpha_{k} Z_{k}+\alpha_{p} Z_{p}+\varepsilon_{k}
$$

where, as in (1) $W_{k}$ and $W_{p}$ measure the log of child and parental wealth. The variables $Z_{k}$ and $Z_{p}$ are vectors of child and parental controls whose explanatory role is being assessed. The extent to which the controls account for the intergenerational wealth elasticity is measured by the extent to which the estimated coefficient $\delta_{2}$ differs from $\delta_{l}$ (estimated from (1)).

\footnotetext{
9 These results are robust to the inclusion of age-income interactions, higher order income controls, and the predicted measures of income discussed below.
} 
We measure education as the completed years of schooling of parents and children. Asset ownership is measured by a binary variable indicating that the parent or child reports owning the particular asset. Measuring lifetime income is more difficult. Theoretical models suggest that wealth is determined by the level, growth and expected variance of lifetime wealth. Empirical measures of these dimensions of lifetime income are not readily at hand because we do not observe the full record of individuals' lifetime earnings.

We use two methods to deal with this problem. The first proxies for lifetime income using the average of the actual family labor income over multiple years. This method will average out transitory earnings shocks and classical measurement error present in yearly survey measures of family labor earnings. For parents, this average is over the years 1983-1987, while for children it is over the years 1992-1996. To capture potential non-linearities in the relationship between income and wealth, we also include the square of average labor income.

The second method first pools all of the data in the PSID for the sample years 1980 to 1997 for non-retired persons aged between 25 and 64 in the particular year. Within race, sex, occupation and educational cells, we then estimate regressions of annual family labor income on age and age squared. ${ }^{12}$ This procedure provides a measure of the expected total labor income earned by households in each race-sex-occupation-education cell, as well as the shape of their lifetime labor income profiles between the ages of 25 and 64. Using the coefficients on age and age squared from these regressions, we predict the family labor income, $\hat{Y}_{c, A}$, for households in each as cell, $c$, earned

101996 income (reported in the 1997 survey) is the latest year of income that is currently available from the PSID.

11 For robustness, we included up to a quartic in income in all of the specifications. The results reported in the remainder of the paper (using the quadratic in income) were identical to the results when a quartic in income was used.

12 We used 9 occupational categories, 3 education classes (less than high school, exactly high school and more than high school), white and non-white race cells and whether the head was male or female. In total, we estimated the expected income profile separately for 97 occupation-education-race-sex cells. There were less than 108 possible cells either because there were no observations in some cells or because there were to few observations in these cells to run a meaningful regression. In such cases, some cells were grouped together. 
at every age, $A$. We use these predicted measures as proxies for the different aspects of lifetime income.

To proxy for the level of lifetime family labor income, $\hat{Y}_{c, \text { lifetime level }}$, we sum the family labor income at every age in each cell, $\hat{Y}_{c, A}$, from $A=25$ to $A=64$. Specifically,

$$
\hat{Y}_{c, \text { lifetime level }}=\sum_{A=25}^{A=64} \hat{Y}_{c, A}
$$

To proxy for future income growth, we compute the fraction of lifetime income which the person is predicted to receive beyond the last age he is measured in the data. That is, if we measure the wealth of a person in cell, $c$, at age $A^{*}$, the fraction of income expected to be earned, $\hat{Y}_{c, A^{*}, \text { growth rate }}$, is measured as:

$$
\hat{Y}_{c, A^{*}, \text { growth rate }}=\sum_{A=A^{*}}^{A=64} \hat{Y}_{c, A} / \sum_{A=25}^{A=64} \hat{Y}_{c, A}
$$

Finally, we proxy for expected future variance of a person's future lifetime income by using the average income variance across individuals in the different race, occupation, education and sex cells.

We also decompose the portion of the wealth correlation due to the expectation of future parental bequests and past parental gifts. In the analysis sample, parents are still alive so that children have not yet received bequests. However, the expectation that a bequest might be received in the future could cause children to hold less wealth than otherwise, and parents - those making the bequest - to hold more. The PSID, in 1994, asked respondents about their probability of leaving a bequest of $\$ 10,000$ or $\$ 100,000$. No information was asked about how much of a bequest the household expected to receive. We estimate the expected bequests to a particular child as the maximum probability that their parent would leave a 10,000 or 100,000 bequest multiplied by the

\footnotetext{
${ }^{13}$ This idea was recommended to us by Orazio Attanasio. We are grateful for his suggestion.
} 
amount of the bequest, divided by the number of children the parent has. In the sample, $24 \%$ of parents expect to leave no bequest. Among those leaving a bequest, the average expected bequest to each child was $\$ 35,264$. We also included a dummy variable equal to 1 if the parent reported that they planned to leave a $\$ 100,000$ bequest with certainty.

In each of the wealth supplements, households are asked if they received gifts totaling more than $\$ 10,000$ over the last five years. If the household answered yes to that question, they are asked to report the exact amount of the gifts that they received. We use this report as the measure of previous gifts. One obvious limitation of the gift measure is that small gifts are not recorded. Unfortunately, this is only information about past gifts received in the data. However, given the size of parental wealth for most households, these 5-year total gift measures likely capture all non-trivial parental wealth transfers.

Tables 4 reports the decomposition of the intergenerational wealth elasticity. There are five columns in the table. The first column of numbers reports the coefficient on log parental wealth from regressions of $\log$ child wealth on $\log$ parental wealth plus additional parental and child controls. The controls in the particular regression are indicated in the first column of the table. The third column reports how much of the overall elasticity is explained by the particular factors. The fourth column, relevant only for panel $\mathrm{B}$, shows the how much of the elasticity is explained by a factor once income is already accounted for. The $R$-squared statistic for the associated regression is in the last column.

Panel A of the table shows how much of the age-adjusted intergenerational wealth elasticity is explained by different factors, considered individually. The first row shows the raw age-adjusted intergenerational wealth elasticity of 0.37 estimated from regression (1). The next row in the panel shows that when parental and child lifetime incomes are added to the regression, proxied by the measures discussed above, the estimated elasticity falls to 0.18 . Thus, fifty-two percent of the age- 
adjusted elasticity is explained by the fact that the lifetime incomes of parents and children are very similar. Given that income explains only one-half of the intergenerational income elasticity, however, implies that parent and child wealth is correlated for reasons beyond the capital market imperfections discussed in much of the theoretical literature explaining the intergenerational income correlation (Becker and Tomes (1979, 1986), Loury (1981)).

The third row in Panel A assesses the effect of education. Adding controls for parental and child completed schooling lowers the wealth elasticity to 0.26 . The fact that parental and child human capital is similar accounts for twenty-eight percent of the similarity in their wealth. The table shows that expected bequests and previous gifts, by themselves, explain approximately $17 \%$ of the age-adjusted elasticity. The effect of portfolio choice is much larger. The final row in the first panel shows that thirty-six percent of the intergenerational wealth elasticity is attributable purely to the fact that parents and children chose to hold similar types of assets - housing, stocks, and businesses.

One problem with the decomposition in Panel A, in which the different factors are separately controlled for, is that their effect on the wealth elasticity net of income is not evident. This is of particular concern since all of the additional controls are functions of child and parental income. The third column of Panel B of Table 4 assesses how much of the age adjusted intergenerational wealth elasticity is explained by different factors after controlling for income. The second row of Panel B shows that controlling for parental and child education when income is already accounted for only changes the estimated elasticity by 0.008 percentage points. This implies that education only explains an additional $2 \%$ of the age adjusted wealth elasticity ( 0.008 divided by 0.365$)$. Also trivial is the effect of expected bequests and transfers after income adjustment: these explain only an additional 4 percent of the wealth relationship. These results show that virtually all of explanatory effect of intra-vivos transfers, education, and expected bequests is subsumed in the effect of the 
parent-child income correlation. This should not be surprising given that received gifts, expected bequests and years of schooling are highly correlated with parent and child income measures.

The last row of Panel B indicates that the same cannot be said about portfolio decisions. Table 3 shows that portfolio choice - especially for home and business ownership - is highly persistent across generations, after controlling for income. Saving propensities, proxied by portfolio allocation, explains an additional 11 percent of the parent-child wealth elasticity. Jointly, similarities in portfolio composition and income explain $64 \%$ of the raw age-adjusted elasticity from the first row of the table. These results are very intuitively appealing. They demonstrate that the principal reason that parents and children have similar wealth is because they generate similar flows of economic resources, as measured by their incomes. The next most important reason is that parents and children make similar portfolio investment decisions out of the resources they generate. Together, these two factors explain almost two-thirds of the intergenerational wealth relationships presented in this paper. The powerful effect of income and portfolio choice is reinforced by the results from the last panel, in which we simultaneously control for all of the factors. All of the factors together account for sixty-five percent of the raw age-adjusted elasticity - only a tiny amount larger than the effect of income and portfolio choices only. 14

A natural question is where in the distribution the effects shown above apply. Do income and portfolio choice explain the wealth elasticity similarly at both the high and low end of the distributions? Table 5 is a transition matrix which allows us to answer this question. The numbers in bold face represent the transition matrix after the log of parental and child wealth are adjusted for

\footnotetext{
${ }^{12}$ The inclusion of other controls which could affect the parent-child wealth correlation did not significantly change the results presented in the last row of Table 4. In various specifications, we included controls for parent and child health, whether the parent and child lived in the same state, the marital status of both the parent and child, whether the parent or child was divorced, the work status of wives in married parent and child household units, the race of the parent and the child, and the number of children in both the parent's and the child's household. With the inclusion of all of these controls, the coefficient on parental wealth fell to 0.101 , a $72 \%$ decline from the raw, age-adjusted intergenerational wealth elasticity.
} 
age, income and portfolio choice. For easy comparability, we present in italics the transition matrix shown earlier in which log parental and child log wealth is adjusted only for age.

The table shows that the effect of income and portfolio choice summarized in Table 4 applies throughout the distribution. Relative to the raw age adjusted entries in italics, most of which are dramatically different from 0.2 , once income and portfolio choice are accounted for, the transition matrix becomes close to what we would expect if there was random sorting. For example, whereas parents in the fifth quintile of the age parental log wealth distribution had only a 11 percent chance of having in a child in the lowest quintile of the child wealth distribution, much of this is because of income and portfolio choices. When these are accounted for, the fifth column of the table shows that the probability of a "rich" parent having a "poor" child is 17 percent. At the other extreme, when income and portfolio choices are ignored, parents in the lowest quintile have a thirty-six percent chance of having their child in the same position in the children's wealth distribution. Adjusting for income and portfolio choices causes this probability to fall by thirteen percentage

points to only twenty-three percent. Notice that the chi-squared test for the first entry in Table 5 rejects random sorting. Some persistence remains even after controlling for income and portfolio composition.

Overall, Table 5 reinforces the main lesson from Table 4: the wealth of parents and children is similar mainly because parents "pass on" to their children comparable incomes and savings behavior. However, the decomposition shows clearly that a significant fraction of the wealth elasticity remains unexplained after accounting not only for income and portfolio choice, but expected bequests, past gifts and education as well.

\section{The Role of Preferences}

Apart from the factors assessed in the decomposition in the previous section, theoretical models emphasize the role of preferences such as discount rates and risk tolerance in determining 
wealth holdings. Might saving preferences be the factor which accounts for the unexplained portion of the intergenerational wealth elasticity?

Parents and children share genes and, for at least part of their lives, live in the same environment. There is thus reason to suspect that their preferences should be similar. But, even if parents' and children's preferences are related, is not the effect of this relationship on the intergenerational wealth elasticity subsumed in the decompositions above which control for parent and child asset choice? This would only be true if any similarity in preferences between parents and children: (a) was a significant determinant of parents' and children's tendencies to own to the similar portfolio, and (b) affected the intergenerational wealth relationship only through its effect on asset holdings.

Disentangling these issues is difficult, chiefly because data on "preferences" are not usually available in survey data. However, new experimental data available in the PSID allows us to assess how a particular set of preferences is related between parents and children, the impact of preferences on portfolio choice, and the effect of preferences on the intergenerational wealth elasticity.

We use data from a 1996 supplement to the PSID which measures respondents' risk tolerance. The risk tolerance questions were only asked of working PSID respondents in the 1996 survey. Because of this restriction, the sample used to analyze the similarity in risk tolerance is different from the samples used in the above analyses. From the original sample, there were 781 parents and 1,316 children eligible to answer the risk tolerance question. The sample size for parents is smaller because a greater proportion of them were retired as of 1996 (even though they were working when we measured their wealth in 1984 and 1989). The new sample, a subset of the original sample, had 583 parent-child pairs where both parent and child provided non-missing answers to the risk tolerance questions.

The risk tolerance question in the PSID is: 
"Suppose you had a job that guaranteed you income for life equal to your current, total income. And that job was (your/your family's) only source of income. Then you are given the opportunity to take a new, and equally good job with a 50-50 chance that it will cut your income by a third or, on the other hand, it could double your income with a 50-50 probability. Would you take that new job?"

Based on their responses to this question, respondents are asked a series of follow-up questions about jobs that double income with a 50 percent probability or either cut income by, $10 \%, 20 \%$, $50 \%$, or $75 \%$ with a 50 percent probability. Assuming a CES utility function and correcting for measurement error, the PSID reports four distinct categories of risk tolerance based on the household's response. 1.5

We classify a respondent's risk tolerance as "very low", "low", "medium" or "high" corresponding to the four categories the PSID reports. The proportion of children with "very low", "low", "medium" and "high" risk tolerance measures were, respectively, 39\%, 17\%, 20\% and 24\%. For parents, the corresponding proportions were $67 \%, 11 \%, 7 \%$ and $15 \%$.

The risk tolerance measures in the PSID were computed from an identical set of questions and an identical procedure to that used by Barsky et. al (1997) with data from the Health and Retirement Study $(H R S)$. Barsky et. al summarize how the risk tolerance parameters are computed and show that they predict risky behaviors in the HRS. Consistent with the results reported above, they also find that risk tolerance falls with age.

Table 6 examines how risk tolerance is related between parents and children. It presents linear probability estimates of the likelihood that a child belongs to a risk tolerance category, given the risk tolerance of his parents. In all of the regressions, parents in the "very low" risk tolerance category are the omitted group. The results in the columns labeled A are from regressions of child risk tolerance on parental risk tolerance and no other controls. The table reveals substantial raw similarity in risk tolerance between parents and children, especially at the tails. Children with a

\footnotetext{
15 Assuming CES preferences, the four risk tolerance categories ("very low", "low", "medium" and "high") correspond to estimated risk aversion measures of 6.67, 3.57, 2.86 and 1.75, respectively. See Barsky et al (1996) for a discussion of how the measures were calculated.
} 
"very low" risk tolerance are least likely to have parents whose tolerance is "high". Children with "high" risk tolerance are almost 16 percentage points more likely to have parents whose risk tolerance is "high" rather than "very low". Given that the base probability that a child has a "high"" risk tolerance is twenty-four percent, this effect is quite large. Notice that children with "low" and "medium" levels of risk tolerance have no statistical relationship to their parent's risk tolerance measure. The same basic pattern is evident in columns B of the table, where the regression also controls for the child's age, education, predicted and actual income and wealth.

The results are quite striking. The risk tolerance measures are derived from hypothetical question posed to parents and their adult children. These people do not live in the same home, and, in general, had not done so for a long time by the date that the questions were posed. Yet, we find that their stated willingness to undertake hypothetical gambles is correlated.

How much of the tendency for parents and children to own the same assets derives from them having similar preferences? Table 7 presents a series of regression showing a child's propensity to hold various assets for households that answered the risk tolerance questions. Reassuringly, the basic results about the intergenerational tendency to own assets, presented in the first two columns of each section, are virtually identical to the results shown earlier for the entire sample. There is a raw parent child similarity in stock ownership which no longer exists once controlling for income. Business and home ownership are correlated across between parents and children, even after controlling for income.

The last regression for each of the assets add controls for parent and child risk tolerance categories. We only show the results for the child risk tolerance measures to show whether the risk tolerance measures have any predictive power for the child's portfolio choice decisions. If these measures mean anything, we would expect people with higher levels of risk tolerance to be more likely to invest in riskier assets such as stocks and businesses. The results are very consistent with 
this prediction. For both stocks and business ownership, persons with higher risk tolerance are more likely to make these investments, relative to the excluded category of "very low" risk tolerance. For business ownership in particular, the estimated effects are strongly statistically significant. Children with the highest level of risk tolerance are 7.3 percentage points more likely to own a business, an increase of 50\% over the mean child business ownership rates. With stock ownership, children with medium and high risk tolerance were also far more likely to own stocks than children with very low risk tolerance, although only the medium risk tolerance group was not statistically different from zero. The results for home ownership - a relatively safe investment - are also consistent with what we would predict, in that there is no statistically significant effect of risk tolerance on home ownership.

If the intergenerational tendency to own assets is driven by risk tolerance, the addition of parental and child risk tolerance measures should dramatically lower the estimated effect of parental asset ownership on a child's asset ownership. The results indicate that for business and ownership, the effect of the parental asset ownership is reduced only slightly when risk tolerance is controlled for. For the other two assets, the risk tolerance measures do not lower the estimated intergenerational relationship in ownership at all. These results suggest that risk preferences explain little of the parent-child tendency to own the same asset. To be sure, preferences other than those for risk affect whether people buy particular assets. Discount rates, for example, likely matter as well. And, it is possible that were there information on these other preferences available in the data, we might find that they explain the remainder of the parent-child asset relationship.

However, another equally plausible explanation is that children make particular investment decisions because of mimicry. Parents who invest in particular assets set an example which their children follow, irrespective of similarities or differences in preferences between parents and 
children. ${ }^{16}$ The example need not be passive. Parents who own a business can teach their children about the skills needed to run a business and may encourage them take over the business or start one of their own. The key point is that it is the fact that the parent owns the asset which raises the child's propensity to do the same, not the fact that their preferences are similar.

Because the parent-child similarity in risk preferences does not appreciably affect the parentchild asset ownership relationship, any effect of risk preferences on the intergenerational wealth elasticity will not be captured by the controls for asset composition in the decompositions presented in the previous section. Table 8 decomposes the intergenerational wealth elasticity for the sub sample which responds to the risk tolerance questions to see how much of the relationship preferences explain, beyond the factors we have thus far studied. We emphasize that this decomposition is on the "risk tolerance" sub-sample.

The first row of the table shows that the intergenerational correlation in age-adjusted log wealth in this sample of 0.362 is very close to that estimated in the full sample. In row 2 , adding the full set of income controls discussed earlier explains about $43 \%$ of the elasticity. This effect is about 9 percentage points smaller than the results in the full sample, but income remains the most important source of the wealth correlation in the restricted sample. Row 3 controls for parent and child income and portfolio composition. As in the full sample, these two factors together explain a substantial portion of the wealth elasticity, though the estimate of seventy percent in this sub sample is slightly larger than what they account for in the full sample. The fourth row adds all of the variables previously studied: income, portfolio choice, education, expected bequests, and previous gifts. In this sub-sample, these factors explain substantially more of the intergenerational wealth

\footnotetext{
${ }^{16}$ One other possibility is that some other behavior, which determines the types of assets people buy, are similar between parents and children. For example, it may be that fathers and sons tend to marry similar women whose patterns of work make the family unit want to hold more risk. Or additionally, that fathers and sons have similar expected life spans. As with the results earlier, these results are robust to the inclusion of parent and child race, marital status, health, location, and family demographic controls.
} 
elasticity than is true for the full sample. Nonetheless, about seventeen percent of the elasticity remains unexplained.

The final row adds parent and child preferences to the set of controls. The risk tolerance measures explain an additional only three percent of the wealth elasticity in the restricted sub sample. These results suggest that, while shared preferences do explain a small portion of the intergenerational wealth elasticity, the effect is dwarfed by the explanatory effect of other factors. Two cautionary notes should be made about this interpretation, however.

First, risk tolerance is only one type of preference. It is possible that some other type of preference about which we have no information might explain more of the remaining wealth relationship. Second, the decomposition in Table 8 is from a sub-sample which differs from the original dataset in certain systematic ways like the ages of parents and children. Because all of the persons in that larger sample did not respond to the risk tolerance sample, we simply cannot conclude for certain whether the effects discussed in this section apply to the sample as a whole.

Whether we use the full sample or the sub sample, the correlation in income between parents and their children is by far the most important factor in explaining the intergenerational wealth elasticity. Portfolio composition has the next most important effect beyond income. The strong correlation in portfolio choice is not determined by income, wealth, and, in the sub sample, risk tolerance. Parental example and mimicry appears the most likely explanation for this association. However, we cannot rule out the fact that parents and children share some other preferences which determine savings behavior, such as rates of time preference. But, we can rule out the similarity in risk tolerance as an explanation. Even though parents and children have similar preferences for risk, we find little independent effect of risk tolerance on the intergenerational wealth elasticity or the intergeneration similarity in portfolio composition. 


\section{Conclusion}

There has been much recent interest in the intergenerational transmission of economic status, but research on the parent-child wealth association has been sparse. This paper documents the relationship between the wealth held by parents and children. In addition, it analyzes alternative explanations for the relationship, shedding light on the importance of different factors which have been discussed in the theoretical literature but about which there has been little previous empirical evidence.

Using data from the PSID, we document substantial intergenerational persistence in wealth. The age-adjusted elasticity of child's wealth with respect to parents' wealth is around 0.37 . These intergenerational relationships are large, especially since we only focus on households who have not yet received bequests from their parents. Results from transition matrices indicate that much of this persistence arises from what occurs in the tails: children of very low wealth or very high wealth parents rarely end with wealth substantially different from their parents'.

We assess alternative accounts for this persistence. We construct indices for the level, expected growth and expected future variance of income, the aspects of income which the theoretical literature has emphasized as being important for household wealth accumulation. We ask, how much of the wealth association derives from the fact that these income measures are intergenerationally related? We find that the effect of comparable incomes is quite large - by far the largest of the possible explanations we study. Over one-half of the wealth correlation is attributable to income, and controlling for income almost completely removes the relative intergenerational persistence in the middle of the wealth distribution.

Despite its very large effect, income does not fully account for the parent-child wealth persistence. Additionally, the effect of previous gifts, education and expected bequests is very small once accounting for income. That we find only a modest effect of education once income is 
controlled for is particularly noteworthy, as previous authors have speculated that wealthy parents principally transfer their position by easing liquidity constraints that their children face in financing schooling. Taken together, these results suggest that parents pass on to their children more than just financial resources.

Theory suggests that similarities between parents and children in the propensity to save out of income as the likely next most important explanation, in a sample where bequests have not yet been received. We find that parents and children tend to allocate their portfolios quite similarly, even after controlling for both the income and wealth of parents and children. We show that this tendency is, apart from income, the next most important reason why wealth tends to be similar across generations. Using only these income and portfolio allocation measures, we can account for between two-thirds and seventy percent of the parent-child wealth relationship.

Why portfolios are similar between parents and children is a question on which we shed some light. We find that having wealthy parents may allow children to undertake investment decisions like stock ownership. But this effect does not hold for other assets, such as business ownership. In general, the fact that a parent owns an asset is enough to predict that the child will as well. On the surface, it would generally be impossible to disentangle 1) whether children mimic or learn from their parents or 2) whether shared preferences such as risk tolerance can explain why portfolio composition is correlated intergenerationally even after controlling for similarities in income. However, using new experimental data in the PSID on risk tolerances, we explicitly address this question.

In the final section of the paper, we show that preferences are, in fact, correlated across generations, especially at the tails of the risk tolerance distribution. Moreover, for both parents and children, asset ownership varies in a predictable fashion with attitudes toward risk. But, the parentchild similarity in asset composition is not affected with the addition of risk tolerance controls. This 
suggests either that some preference other than prudence matters or that children learn from and/or mimic their parents' savings behaviors, irrespective of the similarity in their preferences. We find further that risk tolerance only explains a very modest portion of the intergenerational wealth association, once asset composition and income are accounted for. Nonetheless, the other results about preferences suggest that analyzing the role that parents play in shaping child preferences is a very interesting area for future research. 


\section{Bibliography}

Altonji, Joseph, and Thomas Dunn (1991). "Relationships Among the Family Incomes and Labor Market Outcomes of Relatives." Research in Labor Economics, 12, pgs 269-310.

Altonji, Joseph, and Thomas Dunn (2000). “An Intergenerational Model of Wages, Hours, and Earnings." Journal of Human Resources, 35(2), pgs 221-58.

Altonji, Joseph, Fumio Hayashi, and Laurence Kotlikoff (1992). "Is the Extended Family Altruistically Linked? Direct Tests Using Micro Data." American Economic Review, 82(5), pgs 1177 - 98.

Barsky, Bob, Tom Juster, Miles Kimball and Matthew Shapiro (1997). "Preference Parameters and Behavioral Heterogeneity: An Experimental Approach in the Health and Retirement Study", Quarterly Journal of Economics, 112(2), pgs 537-79.

Becker, Gary and Nigel Tomes (1979). "An Equilibrium Theory of the Distribution of Income and Intergenerational Mobility.” Journal of Political Economy, 87(6), pgs 1153 - 89.

Becker, Gary and Nigel Tomes (1986). "Human Capital and the Rise and Fall of Families." Journal of Labor Economics, 4, pgs S1-S39.

Blanchflower, David and Andrew Oswald (1998). "What Makes an Entrepreneur?" Journal of Labor Economics, 16(1), pgs 26-59.

Browning, Martin and Annamaria Lusardi (1996). "Household Saving: Micro Theories and Micro Facts." The Journal of Economic Literature, 34(4), pgs 1797-1855.

Carroll, Chris (1994). "How Does Future Income Affect Current Consumption." Quarterly Journal of Economics, 109(1), pgs 111-47.

Charles, Kerwin K. and Erik Hurst (2000). "The Transition to Home Ownership and the Black/White Wealth Gap." Review of Economics and Statistics (forthcoming).

Chiteji, Ngina and Frank P. Stafford (2000). “Asset Ownership Across Generations.” University of Michigan Working Paper.

Cox, Donald, Serena $\mathrm{Ng}$ and Andreas Waldkirch (2000). "Intergenerational Linkages in Consumption Behavior." Boston College Working Paper.

Deaton, Angus (1991). "Saving and Liquidity Constraints.” Econometrica, 59(2), pgs 1221-48.

Evans, David and Linda Leighton (1989). "Some Empirical Aspects of Entrepreneurship," American Economic Review, 79(3), pgs 519 - 535.

Engelhardt, Gary (1996). "Consumption, Down Payments, and Liquidity Constraints," Journal of Money, Credit and Banking, May, pgs 255-71. 
Failrie, Robert (1999). "The Absence of African-American Owned Business: An Analysis of the Dynamics of Self-Employment," Journal of Labor Economics, 17(1), pgs 80 - 108.

Friedman, Milton (1957). A Theory of the Consumption Function. Princeton: Princeton University Press.

Ham, Song and Casey Mulligan (2000). "Human Capital, Heterogeneity, and Estimated Degrees of Intergenerational Mobility." NBER Working Paper No. 7678. April.

Hurst, Erik, Ming Ching Luoh, and Frank Stafford (1998). "The Wealth Dynamics of American Families: 1984 - 1994”. Brookings Papers on Economic Activity, 98:1.

Hurst, Erik and Anna Lusardi (2000). "Entrepreneurship and Household Wealth". Unpublished Mimeo.

Juster, Thomas, James Smith and Frank Stafford (1999). "The Measurement and Structure of Household Wealth.” Labour Economics, 1999.

Kearl, James and Clayne Pope (1986). "Unobservable Family and Individual Contributions to the Distributions of Income and Wealth." Journal of Labor Economics, 4(3) S48-79.

Lawrence, Emily (1991). "Poverty and the Rate of Time Preference: Evidence from Panel Data." Journal of Political Economy, 991(1), pgs 54-77.

Loury, Glenn (1981). "Intergenerational Transfers and the Distribution of Earnings." Econometrica, 49(4), pgs 843-67.

Menchik, Paul (1979). "Intergenerational Transmission of Inequality: An Empirical Study of Wealth Mobility." Economica, 46(184), pgs 349-62.

Modigliani, Franco and Richard Brumberg (1954). "Utility Analysis and the Consumption Function: An Interpretation of the Cross Section Data," in Post-Keynesian Economics, Eds.: Kenneth Kurihara. New Brunswick, NJ, Rutgers University Press, pgs, 388-436.

Mulligan, Casey (1996). "Work Ethic and Family Background: Some Evidence' University of Chicago Working Paper.

Mulligan, Casey (1997). Parental Priorities and Economic Inequality. University of Chicago Press, Chicago, IL.

Samwick, Andrew (1998). "Discount Rate Heterogeneity and Social Security Reform.” Journal of Development Economics, 57, 117-146.

Solon, Gary (1992). "Intergenerational Income Mobility in the United States." American Economic Review, 82(3), pgs 393-408.

Solon, Gary (1999). "Intergenerational Mobility in the Labor Market", in Handbook of Labor Economics, Volume 3, edited by Orley Ashenfelter and David Card. 
Shea, John (2000). “Does Parents' Money Matter?” Journal of Public Economics, 77, pgs 15584.

Venti, Steven and David Wise (2000). "Choice, Chance, and Wealth Dispersion at Retirement." NBER Working Paper No. 7521. February.

Wahl, Jennifer (1985). "Fertility in America: Historical Patterns and Wealth Effects on the Quantity and Quality of Children." Ph.D. dissertation, Department of Economics, University of Chicago.

Warner, John and Saul Pleeter (2001). "The Personal Discount Rate: Evidence from Military Downsizing Programs." American Economic Review, 91(1), pgs 33-53.

Zimmerman, David (1992). "Regression Toward Mediocrity in Economic Stature." American Economic Review, 82(3), pgs 409-29. 


\section{Table 1: Means of Wealth and Demographic Variables for PSID Parent-Child Sample (Standard Deviations in Parentheses)}

\begin{tabular}{|c|c|c|}
\hline Variable & Children (1999) & Parents(1984-1989) \\
\hline Age & $\begin{array}{l}37.5 \\
(7.1)\end{array}$ & $\begin{array}{l}52.0 \\
(7.8)\end{array}$ \\
\hline Average Family Labor Income & $\begin{array}{c}57,200 \\
(50,800)\end{array}$ & $\begin{array}{c}70,400 \\
(60,700)\end{array}$ \\
\hline Percent Owning Stocks & $\begin{array}{c}0.313 \\
(0.464)\end{array}$ & $\begin{array}{c}0.503 \\
(0.500)\end{array}$ \\
\hline Percent Owning a Home & $\begin{array}{c}0.688 \\
(0.464)\end{array}$ & $\begin{array}{c}0.919 \\
(0.276)\end{array}$ \\
\hline Percent Owning a Business & $\begin{array}{c}0.169 \\
(0.374)\end{array}$ & $\begin{array}{c}0.300 \\
(0.458)\end{array}$ \\
\hline $\begin{array}{l}20^{\text {th }} \text { Percentile of Wealth } \\
40^{\text {th }} \text { Percentile of Wealth } \\
60^{\text {th }} \text { Percentile of Wealth } \\
80^{\text {th }} \text { Percentile of Wealth }\end{array}$ & $\begin{array}{c}39,225 \\
88,731 \\
162,728 \\
348,879\end{array}$ & $\begin{array}{c}49,635 \\
99,369 \\
174,889 \\
347,622\end{array}$ \\
\hline Level of Wealth (Mean) & $\begin{array}{c}158,716 \\
(550,272)\end{array}$ & $\begin{array}{c}326,355 \\
(822,990)\end{array}$ \\
\hline Log of Wealth (Mean) & $\begin{array}{l}10.7 \\
(1.7)\end{array}$ & $\begin{array}{l}11.7 \\
(1.5)\end{array}$ \\
\hline
\end{tabular}

* Sample: All PSID parent-child pairs in which: parents were in survey in 1984-1989 and alive in 1989; child was in survey 1999; parent not retired and between ages of 25 and 65 in 1984; child between ages 25 and 65 in 1999; child and parent measured wealth both positive when measured. (1,491 parent-child pairs)

* All data in this table and all subsequent tables weighted using PSID core sample weights.

* All dollar amounts in this table, and all subsequent tables, are in 1996 dollars. 
Table 2: Intergenerational Transition Matrix of Age-Adjusted Log Wealth Position

Parental Age-Adjusted Log Wealth Quintile (1984-1989)

\begin{tabular}{|c|c|c|c|c|c|}
\hline $\begin{array}{c}\text { Child Age-Adjusted Log Wealth } \\
\text { Quintile (1999) }\end{array}$ & 1 & 2 & 3 & 4 & 5 \\
\hline 1 & 36 & 26 & 16 & 15 & 11 \\
\hline 2 & 29 & 24 & 21 & 13 & 16 \\
\hline 3 & 16 & 24 & 25 & 20 & 14 \\
\hline 4 & 12 & 15 & 24 & 26 & 24 \\
\hline 5 & 7 & 12 & 15 & 26 & 36 \\
\hline Total & 100 & 100 & 100 & 100 & 100 \\
\hline
\end{tabular}

* Each element of the matrix above, $\pi_{\mathrm{ab}}$, indicates the probability (in percent) that a child belongs to the $a^{\text {th }}$ quintile of the distribution for children, given that her parents belong to the $b^{\text {th }}$ quintile of the parental distribution. The entries sum to one along the columns.

* See footnote to Table 1 for sample description (1,491 parent-child pairs).

* To get age-adjusted wealth measures, both parent and children's log wealth were adjusted using a first stage $O L S$ regression of log wealth on age and age squared. The correlation of the residuals from the first stage regression is presented in this table.

* Likelihood ratio $\chi^{2}$ statistic that each cell is equal to the other for the unadjusted wealth entries: $\chi^{2}=262.4$ ( $p$-value $<$ $0.001)$. 
Table 3: Similarity in Parent-Child Income, Human Capital and Portfolio Composition (1,491 Parent-Child Pairs)

\begin{tabular}{|c|c|c|}
\hline & $\boldsymbol{I}$ & II \\
\hline Child Outcome Measure (Dependent Variable) & $\begin{array}{c}\text { Coefficient on Corresponding } \\
\text { Parental Outcome Variable }\left(\gamma_{1}\right)\end{array}$ & $\begin{array}{l}\text { Mean of Dependent } \\
\text { Variable }\end{array}$ \\
\hline $\begin{array}{l}\text { Income } \\
\text { Child's Family Log Labor Income }\end{array}$ & $\begin{array}{c}0.301 \\
(0.025)\end{array}$ & 10.7 \\
\hline $\begin{array}{l}\text { Education } \\
\text { 1. Head of Child's Family has Education }<12\end{array}$ & $\begin{array}{c}0.098 \\
(0.016)\end{array}$ & 0.084 \\
\hline 2. Head of Child's Family has Education $=12$ & $\begin{array}{c}0.043 \\
(0.034)\end{array}$ & 0.355 \\
\hline 3. Head of Child's Family has Education $>12$ & $\begin{array}{c}0.325 \\
(0.025)\end{array}$ & 0.561 \\
\hline $\begin{array}{l}\text { Asset Ownership } \\
\text { 1. Dummy: Child Owns Stock }\end{array}$ & $\begin{array}{c}0.162 \\
(0.022)\end{array}$ & 0.313 \\
\hline 2. Dummy: Child Owns Business & $\begin{array}{c}0.096 \\
(0.018)\end{array}$ & 0.169 \\
\hline 3. Dummy: Child Owns Home & $\begin{array}{c}0.167 \\
(0.040)\end{array}$ & 0.688 \\
\hline $\begin{array}{l}\text { Asset Ownership, Net of Income and Education } \\
\text { 4. Dummy: Child Owns Stock }\end{array}$ & $\begin{array}{c}0.028 \\
(0.022)\end{array}$ & 0.313 \\
\hline 5. Dummy: Child Owns Business & $\begin{array}{c}0.073 \\
(0.018)\end{array}$ & 0.169 \\
\hline 6. Dummy: Child Owns Home & $\begin{array}{c}0.089 \\
(0.039)\end{array}$ & 0.688 \\
\hline
\end{tabular}

Regression: $z_{k}=\gamma_{0}+\gamma_{1} z_{p}+\gamma_{2} \operatorname{Age}_{k}+\gamma_{3} \operatorname{Age}_{k}^{2}+\gamma_{4} \operatorname{Age}_{p}+\gamma_{5} \operatorname{Age}_{p}^{2}+v_{k}$

where $z_{k}=$ child outcome variable and $z_{p}$ is the similarly defined parental outcome variable.

Outcome Measures:

* Income: Average child log family labor income is measured over 1992 and 1996. Average parent log family labor income is measured over 1984 and 1988.

* Education: Dummy variable equal to 1 indicating if the head of the household attained $m$ years of schooling (for $m<12, m=12$, and $m>12$ ).

* Asset Ownership: Dummy variable which takes the value of 1 if the household owns portfolio component $j(j=$ stocks, business, and home). Child asset ownership is measured in 1999. Parental asset ownership is measured in 1984.

* Standard errors for the regressions (in parenthesis) are robust to heteroskedasticity and within-family correlation. 
Table 4: Decomposition of Intergenerational Wealth Elasticity:

Estimated coefficient on $\log$ parental wealth from regressions of $\log$ child wealth on $\log$ parental wealth with various additional parental and child controls.

\begin{tabular}{|c|c|c|c|c|}
\hline & $\begin{array}{l}\text { Estimated } \\
\text { Elasticity }\end{array}$ & $\begin{array}{l}\text { Fraction } \\
\text { of } \\
\text { Elasticity } \\
\text { Explained }\end{array}$ & $\begin{array}{c}\text { Additional } \\
\text { Fraction } \\
\text { of } \\
\text { Elasticity } \\
\text { Explained } \\
\end{array}$ & $\begin{array}{c}\text { Adjusted } \\
R- \\
\text { squared }\end{array}$ \\
\hline \multicolumn{5}{|l|}{ A. } \\
\hline Wealth Elasticity, Controlling for Only Age & $\begin{array}{c}0.365 \\
(0.028)\end{array}$ & ---- & ---- & 0.102 \\
\hline \multicolumn{5}{|l|}{ Wealth Elasticity, Controlling for Age and: } \\
\hline Actual and Predicted Income & $\begin{array}{c}0.175 \\
(0.032)\end{array}$ & $52.1 \%$ & ----- & 0.304 \\
\hline Education & $\begin{array}{c}0.263 \\
(0.030)\end{array}$ & $28.0 \%$ & ----- & 0.154 \\
\hline Past Transfers and Expected Bequests & $\begin{array}{c}0.303 \\
(0.032)\end{array}$ & $16.9 \%$ & ----- & 0.112 \\
\hline Portfolio Composition & $\begin{array}{c}0.232 \\
(0.031)\end{array}$ & $36.4 \%$ & ----- & 0.421 \\
\hline \multicolumn{5}{|l|}{ B. } \\
\hline \multicolumn{5}{|l|}{ Wealth Elasticity, Controlling for Age, Income and: } \\
\hline Education & $\begin{array}{c}0.167 \\
(0.032)\end{array}$ & $54.3 \%$ & $2.2 \%$ & 0.310 \\
\hline Past Transfers and Expected Bequests & $\begin{array}{c}0.161 \\
(0.034)\end{array}$ & $55.7 \%$ & $3.6 \%$ & 0.305 \\
\hline Portfolio Composition & $\begin{array}{c}0.133 \\
(0.035)\end{array}$ & $63.6 \%$ & $11.5 \%$ & 0.490 \\
\hline $\begin{array}{l}\text { Education, Past Transfers, Expected Bequests } \\
\text { and Portfolio Composition }\end{array}$ & $\begin{array}{c}0.129 \\
(0.037)\end{array}$ & $64.7 \%$ & $12.6 \%$ & 0.492 \\
\hline
\end{tabular}

* See Footnote to Table 1 for sample description (1,491 parent-child pairs).

* Income controls include all the actual and predicted income controls described in Text (including a quadratic in actual income and age interacted with the actual and predicted income measures).

* Standard errors for the regressions (in parenthesis) are robust to heteroskedasticity and within-family correlation. 


\section{Table 5: Intergenerational Transition Matrix of Age-Adjusted Log Wealth, After Controlling for Lifetime Income and Asset Composition.}

\section{Age, Income and Portfolio Composition Adjusted Position in Bold Age-Adjusted Position in Italics}

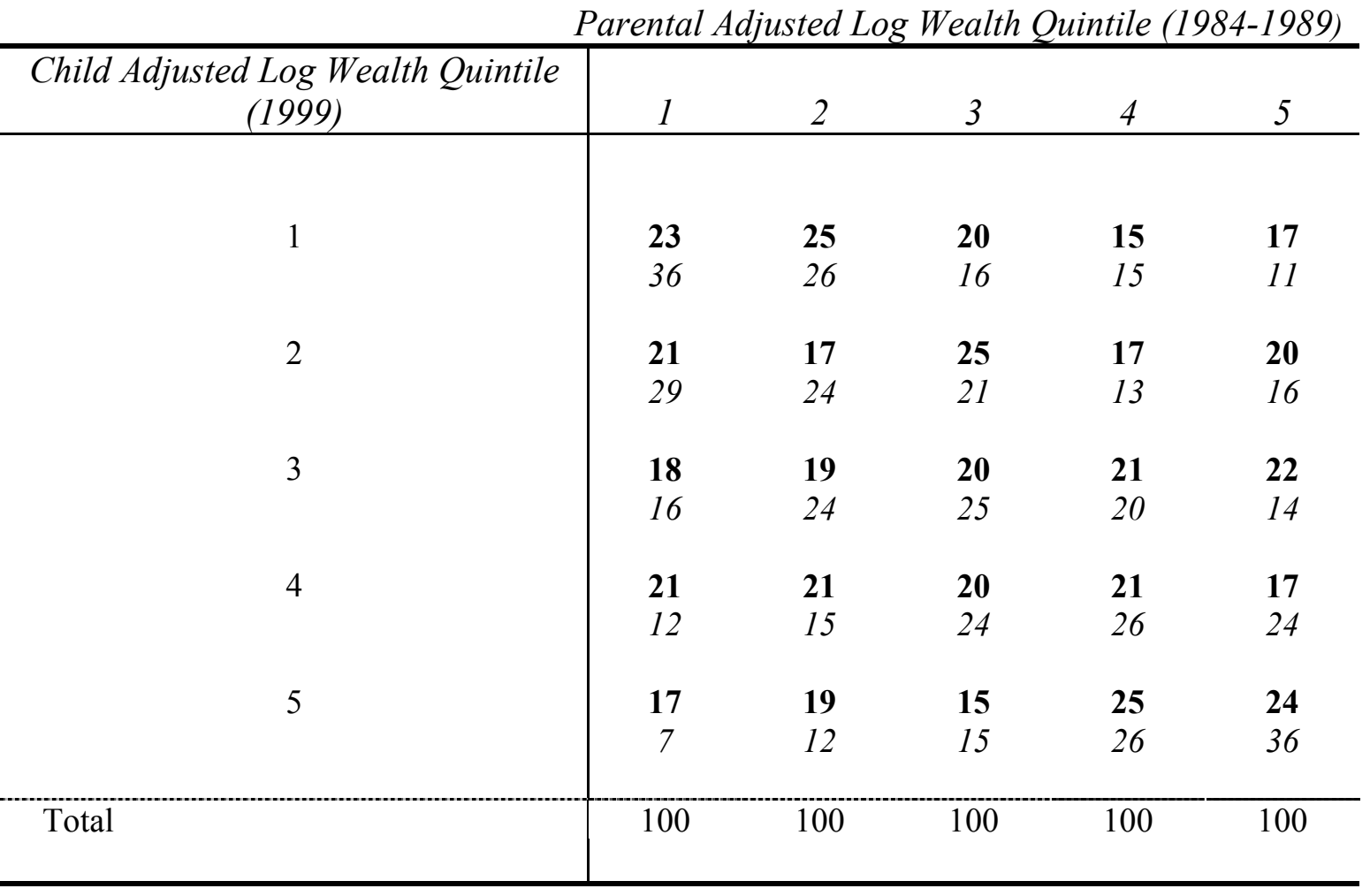

* Each element of the matrix above, $\pi_{\mathrm{ab}}$, indicates the probability (in percent) that a child belongs to the $a^{\text {th }}$ quintile of the distribution for children, given that her parents belong to the $b^{\text {th }}$ quintile of the parental distribution. The entries sum to one along the columns.

* To get adjusted wealth measures, both parent and children's log wealth were adjusted using a first stage $O L S$ regression of log wealth on age and age squared, measures of actual and predicted lifetime income, and binary variables denoting whether the person owned a home, stocks or a business. The correlation of the residuals from the first stage regression is presented in this table.

* See Footnote to Table 1 for sample description (1,491 parent-child pairs).

* Likelihood ratio $\chi^{2}$ statistic that each cell is equal to the other for the unadjusted wealth entries: $\chi^{2}=34.7(p$-value $<$ 0.004). 
Table 6: Linear Probability Estimates of Relationship Between Child and Parent Risk Tolerance Categories

Child's Risk Tolerance Measure

\begin{tabular}{|c|c|c|c|c|c|c|c|c|}
\hline \multirow[t]{2}{*}{ Regressors } & \multicolumn{2}{|c|}{ Very Low } & \multicolumn{2}{|c|}{ Low } & \multicolumn{2}{|c|}{ Medium } & \multicolumn{2}{|c|}{ High } \\
\hline & A & B & A & B & A & B & A & B \\
\hline \multicolumn{9}{|l|}{ Parental Risk Tolerance } \\
\hline Dummy: Low Risk Tolerance & $\begin{array}{c}0.059 \\
(0.065)\end{array}$ & $\begin{array}{c}0.064 \\
(0.066)\end{array}$ & $\begin{array}{c}0.008 \\
(0.051)\end{array}$ & $\begin{array}{l}-0.021 \\
(0.052)\end{array}$ & $\begin{array}{l}-0.054 \\
(0.054)\end{array}$ & $\begin{array}{c}-0.042 \\
(0.054)\end{array}$ & $\begin{array}{c}-0.012 \\
(0.057)\end{array}$ & $\begin{array}{c}-0.001 \\
(0.058)\end{array}$ \\
\hline Dummy: Medium Risk Tolerance & $\begin{array}{l}-0.117 \\
(0.079)\end{array}$ & $\begin{array}{l}-0.125 \\
(0.083)\end{array}$ & $\begin{array}{c}0.072 \\
(0.062)\end{array}$ & $\begin{array}{c}0.039 \\
(0.065)\end{array}$ & $\begin{array}{c}0.081 \\
(0.065)\end{array}$ & $\begin{array}{c}0.107 \\
(0.068)\end{array}$ & $\begin{array}{l}-0.037 \\
(0.069)\end{array}$ & $\begin{array}{l}-0.021 \\
(0.072)\end{array}$ \\
\hline Dummy: High Risk Tolerance & $\begin{array}{c}-\mathbf{0 . 1 3 8} \\
(\mathbf{0 . 0 5 7})\end{array}$ & $\begin{array}{c}-0.098 \\
(0.057)\end{array}$ & $\begin{array}{l}-0.005 \\
(0.045)\end{array}$ & $\begin{array}{l}-0.013 \\
(0.047)\end{array}$ & $\begin{array}{l}-0.010 \\
(0.047)\end{array}$ & $\begin{array}{c}-0.012 \\
(0.049)\end{array}$ & $\begin{array}{c}0.154 \\
(0.050)\end{array}$ & $\begin{array}{c}0.123 \\
(0.053)\end{array}$ \\
\hline
\end{tabular}

* Regression reported in this table: Linear probability model of child risk tolerance category as a function of parental risk tolerance categories without wealth, income and demographic controls (Column A) and with wealth, income and demographic controls (Column B).

* Sample: Persons in the "main" sample defined in footnote to Table 1 who also responded to "risk tolerance" questions asked of persons working in 1996. Sub-sample consists of 583 parent-child pairs.

* For Column B, demographic, income and wealth controls include both parent and child's: age, age squared, log wealth and all actual and predicted income controls.

* Percent of children with 'very low', 'low', 'medium' and 'high' risk tolerance, respectively, 0.39, 0.17, 0.20, and 0.24.

* Coefficients in bold are significant at the 10 percent level.

* Standard errors for the regressions (in parenthesis) are robust to heteroskedasticity and within-family correlation. 
Table 7: Intergenerational Similarity in Portfolio Composition and Risk Tolerance

\begin{tabular}{|c|c|c|c|c|c|c|c|c|c|}
\hline & \multicolumn{3}{|c|}{ I. Child Owns Stock? } & \multicolumn{3}{|c|}{ II. Child Owns Business? } & \multicolumn{3}{|c|}{ III. Child Owns Home? } \\
\hline & $A$ & $B$ & $\bar{C}$ & $A$ & $B$ & $C$ & $A$ & $B$ & $C$ \\
\hline Parent Owns Stock & $\begin{array}{c}0.133 \\
(0.039)\end{array}$ & $\begin{array}{c}0.057 \\
(0.041)\end{array}$ & $\begin{array}{c}0.058 \\
(0.041)\end{array}$ & & & & & & \\
\hline Parental Owns Business & & & & $\begin{array}{c}0.110 \\
(0.033)\end{array}$ & $\begin{array}{c}0.081 \\
(0.034)\end{array}$ & $\begin{array}{c}0.065 \\
(0.034)\end{array}$ & & & \\
\hline Parental Owns Home & & & & & & & $\begin{array}{c}0.245 \\
(0.073)\end{array}$ & $\begin{array}{c}0.145 \\
(0.072)\end{array}$ & $\begin{array}{c}0.147 \\
(\mathbf{0 . 0 7 3 )}\end{array}$ \\
\hline Child is "Low" Risk Tolerance & & & $\begin{array}{c}-0.027 \\
(0.054)\end{array}$ & & & $\begin{array}{c}0.066 \\
(0.046)\end{array}$ & & & $\begin{array}{l}-0.088 \\
(0.052)\end{array}$ \\
\hline $\begin{array}{l}\text { Child is "Medium" Risk Tolerance } \\
\text { Child is "High" Risk Tolerance }\end{array}$ & & & $\begin{array}{c}\mathbf{0 . 1 8 6} \\
(\mathbf{0 . 0 5 1}) \\
-0.021 \\
(0.049)\end{array}$ & & & $\begin{array}{c}0.120 \\
(0.044) \\
0.087 \\
(0.042)\end{array}$ & & & $\begin{array}{c}0.028 \\
(0.049) \\
-0.009 \\
(0.046)\end{array}$ \\
\hline Parent and Child Age Controls & Yes & Yes & Yes & Yes & Yes & Yes & Yes & Yes & Yes \\
\hline Parent and Child Income Controls & No & Yes & Yes & No & Yes & Yes & No & Yes & Yes \\
\hline Parent and Child Risk Tolerance Controls & No & No & Yes & No & No & Yes & No & No & Yes \\
\hline Adjusted R-Squared & 0.030 & 0.115 & 0.138 & 0.029 & 0.062 & 0.072 & 0.087 & 0.180 & 0.181 \\
\hline
\end{tabular}

* Table reports the linear probability regression results of child portfolio ownership on parental portfolio ownership with and without income and risk tolerance controls.

* Sample: A sub sample of the 'main' sample of analysis described in the footnote for Tables 1 . The additional restriction imposed is that both parent and child had to have been working in 1996 and had to give non-missing responses to the risk tolerance questions (see text for full discussion). (583 parent-child pairs)

* Age controls include: Age and age squared of both parent and child.

* Income and Education controls include: All human capital and income controls described in regression 5 of Table 3 for both parents and their children .

* Risk Tolerance controls include: Three risk tolerance categories ('low', 'medium' and 'high') for both parents and children. The omitted group was 'very low' for both groups.

* Base probability that the child owns stock, a business, or a house, respectively: $0.350,0.186$, and 0.691 . 
Table 8: Decomposition of Intergenerational Wealth Elasticity, Including Effect of Preferences

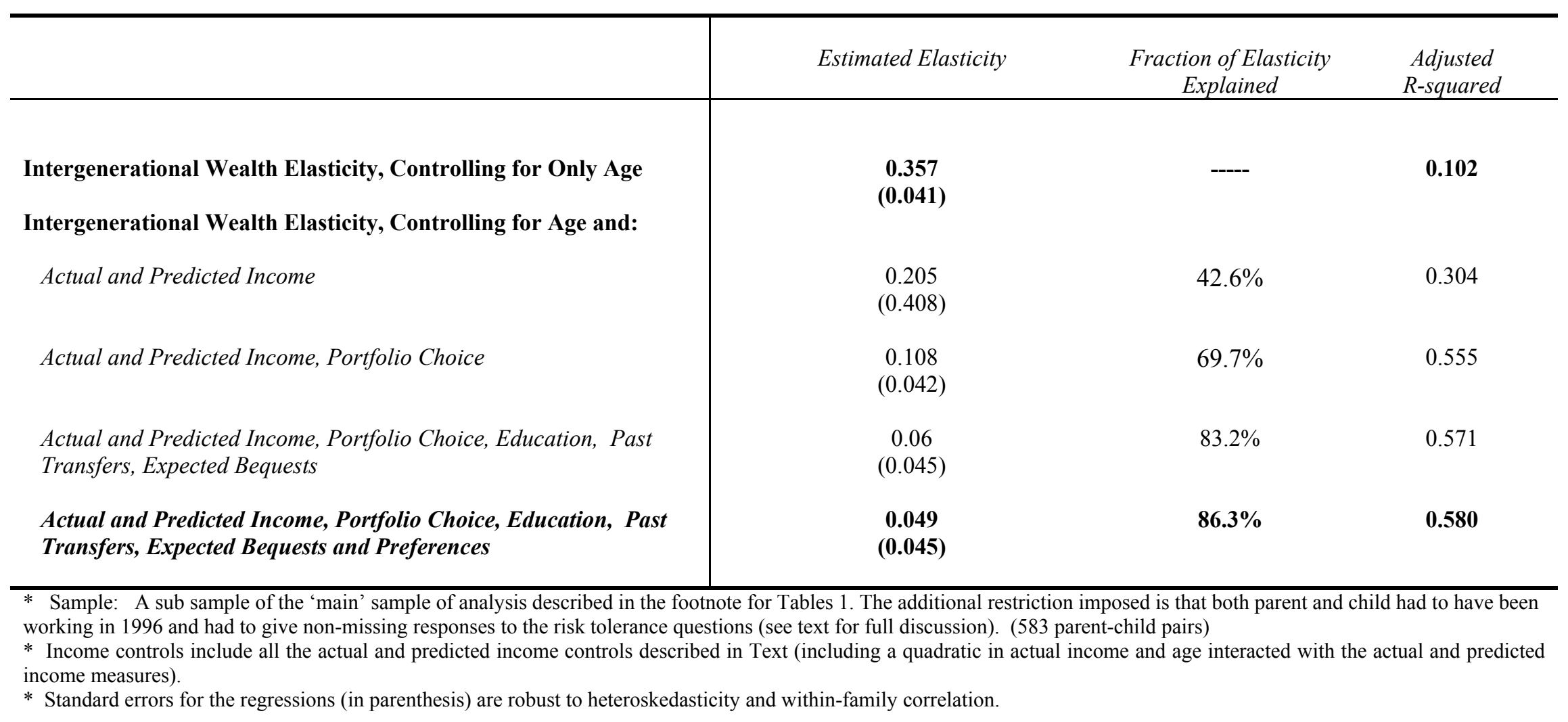

